\title{
Ultramafic-mafic rocks of the Eastern European Craton and Their Diamond Potential
}

\author{
Kazimieras Kepezhinskas ${ }^{1}$ and Pavel Kepezhinskas ${ }^{2}$ \\ 1. Institute for Geology, Schevchenkos Str. 13, Vilnius 2600, Lithuania \\ 2. Department of Geology, University of South Florida, Tampa, Florida 33620, USA
}

Abundant geological, stratigraphic, structural, geophysical and geochemical data indicate that Eastern European Craton (EEC) has the structure, geology and composition typical of other classic Precambrian cratons with thick $(>45 \mathrm{~km}$ ) mature continental crust formed before Riphean (Late Proterozoic) time. East European craton includes Archean high-grade granulite terranes (west Baltic and Belorussky terranes, granulite terranes within Ukrainian and Baltic shields) intersected by Lower Proterozoic mobile belts which include relics of classic greenstone belts similar to South African (Barberton) and West Australian (Kalgoorlie) greenstone terranes (Vetrenny, Dzukia, and Voronezh belts). EEC mobile belts exhibit multiple stages of intense crustal re-working and re-mobilization which precisely correlate with world-wide stages of crustal production and evolution defined in other ancient cratons.

Average thickness (>45 km) and structure of the EEC continental crust is typical of the mature continental crust of the other diamondiferous Precambrian cratons. Seismic and electromagnetic anomalies identified within the lower crust of EEC resemble crustal anomalies associated with productive Zimny Bereg (Arkhangelsk) and Mirny (Siberian province) kimberlite fields. East European cratonic crust was multiply rifted along its margins which is manifested by emplacement of various ultramafic-mafic magmatic rocks (Early Archean, Early Proterozoic, Riphean-Vendian, and Late Devonian-Early Carboniferous).

Two major alternative tectonic models explaining the structure of the Eastern European craton currently exist in a literature. Scandinavian geologists suggested that the EEC basement represents an agglomerate of three rather large Precambrian crustal segments (essentially a composite terrane) - e.g., Fennoscandia, Sarmatia, and Volgo-Uralia. Another model, favored by Russian, Belorussian, and Baltic geologists suggests that the EEC is built of numerous blocks and slivers of Archean $(>2.5 \mathrm{Ga}$ ) crust (Archean crustal terranes) set in a "matrix" of Early Proterozoic mobile belts.

Archean to early Proterozoic ultramafic-mafic rocks are either mainly concentrated within the wellpreserved greenstone belts (Karelsky granite-greenstone region) or found as fragments of the greenstone belt terranes within the younger mobile belts (Dzukia greenstone belt terrane within the InchukalnskyPodliasky mobile belt). Ultramafic-mafic rocks form variably metamorphosed and deformed tectonic blocks and lenses, boudines, nappes and fragments of imbricated thrust sheets as well as (to a lesser extent) fragments of the layered ultramafic-mafic plutonic complexes. Archean to early Proterozoic ultramaficmafic rocks include mafic two-pyroxene gneisses, charnokites, amphibolites, metagabbros, diabases, serpentinites, metaperidotites, metapyroxenites, and komatiites. Chemically, these rocks resemble ultramafic-mafic portions of the Phanerozoic oceanic crust and/or (in case of clearly layered ultramaficmafic rocks) portions of Bushveld-type layered intrusions.

The Riphean-Vendian ultramafic-mafic magmatism of the EEC can be sub-divided into two events 
(episodes) which differ from each other in volumes, eruptive styles, and, to a lesser extent, bulk chemical composition: Riphean (1650-670 Ma) and Vendian (670-590 Ma). The earliest Riphean event includes predominantly mafic dikes and basaltic lavas associated with pyroclastic and sedimentary rocks. These volcanic-sedimentary sequences were formed in the small grabens and syncline structures mainly along the margins of the Baltic and Ukranian shields.

Late Devonian-Early Carboniferous magmatic rocks manifest a cratonic stage of the EEC evolution and were formed during extensive rifting which to a large extent followed general spatial pattern of the older Precambrian rifting zones. Three Late Devonian-Early Carboniferous magmatic complexes are identified on the basis of their composition and emplacement style: 1) continental flood basalts; 2) sub-alkaline and alkaline ultramafic-mafic rocks and spatially associated kimberlites and kimberlite-like rocks; and 3) ultramafic to mafic lamprophyres associated with carbonatites, which form large plutonic complexes and accompanying ring-dikes and dike swarms. All these rock groups are related to the post-subduction rifting along the margins of major structures of the East European craton and were emplaced in large grabens and aulacogens.

Late Devonian-Early Carboniferous continental flood basalts (CFBs) mainly occupy the southern portion of the EEC. Late Devonian flood basalts were erupted on the eastern and southeastern slopes of the Voronezh anticline (Mamonovsky volcanic complex). Middle Devonian (?)-Late Devonian CFBs were developed along the southwestern slope of Voronezh anticline (Belgorodsky volcanic complex). Late Devonian flood basalts are also common within the Dniepr-Donets depression (rift) and Donetsky Range (Pripyatsky-Dneprovsky volcanic complex).

Besides continental flood basalts, the pervasive rifting within EEC margins produced a variety of subalkaline and alkaline igneous rocks (trachybasalts, trachydolerites, shonkinites, leucite tephrites, porphyritic monzonites, phonolites) and spatially (but not necessarily genetically) associated kimberlites and kimberlitelike (including extensively contaminated by wall-rock) rocks. Three major ultramafic alkaline provinces are recognized within the western, southern and northern part of the EEC: 1) western Belorussian province, 2) northern Arkhangelsk (Zimny Bereg) province, and 3) southern Donbass province (Ukraine). There is also an undervalued kimberlite potential within the NE corner of the EEC - Timan-Pechora region and also within the eastern margin of the East European craton within the junction zone with Ural-Mongolian orogenic belt.

All major Precambrian structures within the EEC are oriented perpendicular to the original strike of the Iapetus ocean-Tornquist sea system. For example, all structures of the SW part of the EEC basement (Belorus and Lithuania) are perpendicular to the Teisseyre-Tornquist zone which marks the SW boundary between the EEC and Paleozoic terranes of the Western Europe. In the west and northwest of the EEC (Baltic shield, Zimny Bereg of the White Sea), Precambrian basement structural style is dominated by SENW-oriented structures which are also perpendicular to the Iapetus ocean structures (Norwegian Caledonides) in this part of the craton. Described relationships between the Archean to early Proterozoic and post-early Proterozoic structures suggest that the Iapetus-Tornquist oceanic basin system was created through the large-scale extension of the mature Archean-early Proterozoic continental crust. Fragments of this ancient continental crust are preserved within the EEC basement. 
Subduction of the Iapetus-Tornquist paleo-oceanic crust was completed in early Devonian and caused a new episode of pervasive late Devonian-early Carboniferous rifting manifested by emplacement of the alkaline ultramafic rocks. Within the parts of the craton where Precambrian crystalline rocks were covered by Cambrian-Silurian sediments (SW part of the EEC- Belorus and Lithuania; N part of the EEC - Zimny Bereg), new late Devonian-early Cambrian rifts were developed parallel to the Iapetus-related subduction zones and perpendicular to ancient Precambrian rifts. In contrast, within the areas with limited subsidence and low sedimentation rates (Baltic shield), Precambrian rifts were re-activated during the late Devonianearly Carboniferous extension phase and original (Precambrian) orientation was preserved. This suggests that the late Devonian-early Carboniferous rifting and associated alkaline ultramafic magmatism within the EEC was preceded and most probably triggered by the pre-late Devonian subduction of the Iapetus oceanTornquist sea oceanic crust.

Two tectonic events are of importance in typical diamondiferous cratonic settings: 1) subduction of paleooceanic lithosphere below craton and 2) subsequent rifting of cratonic crust with development of deepseated mantle detachment faults which are capable of promoting of fast ascent of ultramafic alkaline magmas. All important geologic/structural and petrologic/mineralogic conditions of diamond transport and emplacement were released during two stages of the EEC crustal evolution: I. Lower Proterozoic subduction of Archean paleo-oceanic crust below the EEC followed by Riphean-Vendian (Late Proterozoic) rifting and emplacement of ultrapotassic (lamporitic) magmas and II. Early Devonian subduction of Ordovician-Silurian ocean floor of the Iapetus Ocean-Tornquist sea system followed by Late DevonianEarly Carboniferous rifting and emplacement of kimberlitic, lamprophyric, and alkaline basaltic magmas.

Two types of potentially diamondiferous magmas are identified within the EEC: Riphean (Late Proterozoic) lamproitic rocks and Late Devonian-Early Carboniferous kimberlite and kimberlite-like rocks. These rocks were emplaced within major rift systems, but in majority of cases (except Onezhsky graben - Arkhangelsk kimberlite province and South Donbass - Petrovsky kimberlite field) sedimentation within rift grabens was too heavy and covered potentially productive pipes with more than $200 \mathrm{~m}$ of sedimentary rocks. Smallest thicknesses of sediment overlying pipes or pipe-like magnetic anomalies (southern Lithuania, northwestern Lithuania and southwestern Latvia) are localized within structural domes (rift shoulders) ajacent to rift grabens. 